\title{
The Traditional Liner Companies and the Container Lines
}

In the 1800 s maritime trade underwent a revolution and much can be explained by four factors: steam engines, iron hulls, screw propellers, and a deep sea cable network. During the second half of the 19th century, the contours of the new maritime market were clearly visible. There were passenger liners which on regular services transported mail and passengers between North America, Europe and the Far East. There were cargo liners which transported cargo and some passengers between developed and imperial markets. And there was tramp shipping which carried spot cargoes, often bulk cargoes, such as coal and grain ${ }^{1}$. While tramp ships had a long history, the liner companies were a product of the transport revolution in shipping.

The passenger liners were the fastest, operating at a speed of 16-25 knots. They were symbols of national engineering prowess. The passenger liners were fitted for passengers, obviously, but also for some cargo. The companies in this business were for example Cunard, White Star, North German Lloyd and Holland America Line.

The cargo liners were not as fast, often operating at a speed of about 12 knots, but they were highly flexible. They had many decks to allow for loading and discharging in several ports, and compartments for specialty cargo, such as refrigerated goods. They could carry some passengers, but towards the end of the 19th century, most of the passengers were carried by passenger liners. The liner trades loaded and discharged in several ports and the stowing and discharging operations were complicated and time-consuming. The cargo could come in bags, bales, cases, and casks.

Soon after the birth of the cargo liners, in the 1870s, the conference system was developed. Major British companies such as $\mathrm{P} \& \mathrm{O}$, Alfred Holt and Glen Line, realized that competition was forcing prices down to levels that did not cover their costs. To keep prices up there was a need to collaborate. The first conference was that between the United Kingdom and Calcutta, formed in 1875. The rates were set, the number of sailings limited, and the participant companies should not grant preferences or concessions to shippers. This was not appreciated amongst the shippers. To understand the independent reefer

1 Based on Stopford 2009, p. 23-32, 35-41, and chapter 13. 
operators, it is important to understand the control that conferences had on maritime trade, and the alternative that the independent reefer operators and other tramp shipping companies could provide to shippers. However, conferences continued to develop and by the 1950 s there were 360 liner conferences in the deep-sea trades, which regulated sailings and freight rates. Each had between two and 40 members. Examples of the then dominating liner companies in the 1950s were P\&O, Blue Funnel, and Hamburg Süd.

In the 1960s, containerization had a great impact on the liner companies. The labour-intensive stowing and discharging of standardized containers could be mechanized. Many cargo liners were very inefficient spending up to $50 \%$ of their time in port. Containerization also led to additional benefits such as the reduction of pilferage. And the cargo could more easily be re-loaded onto rail or barge with less delay. Apart from containerization, the traditional liners were affected by the development of airlines which took over passenger and mail trades. Also, as colonies gained independence, the liner companies lost their privileged position in many of its core trades. The passenger liners dissappeared within a decade, or were converted to cruise ships, and the cargo liners were gradually replaced by container vessels and specialty ships, such as reefers. Similarly to the independent reefer operators, the liner companies thought that containerization might be too inflexible and looked for solutions based on palletisation and the use of ro-ro vessels.

The first container ships purpose-built to transport refrigerated containers were built by OCL and ACT in 1969. They had a capacity of $45^{\circ} \mathrm{TEU}$ reefer containers. In 1970 the Sydney Express was delivered to Hapag-Lloyd and the Columbus New Zealand to HSDG in 1971. Centralized cooling units ducted cold air to insulated, porthole containers. ${ }^{2}$

The market changes ushered in by containerization, in combination with the penetration of market competition, led to a weakening of the conference system. The conference system was gradually changed to a more open system with stabilization agreements and alliances.

The container lines are the new generation of liner companies, such as $\mathrm{P} \& \mathrm{O}$, Blue Star Line, Hamburg Süd, and Johnson Line which regularly carried refrigerated cargo. While containerization of dry cargo was difficult in itself, containerization of reefer cargo was much more demanding. Furthermore, containerization required and continues to require significant investments

2 Wijnolst and Wergeland 2009, p. 288. 
TABLE 13 World's largest container ship fleets (TEU)

Container line

Maersk Line

Mediterranean Shipping Company

CMA CGM

cosco Shipping

Evergreen

Hapag-Lloyd

APL

China Shipping (CSCL)

Hanjin Shipping

MOL
Capacity (TEU)

$2.62 \mathrm{~m}$

$2.19 \mathrm{~m}$

$1.35 \mathrm{~m}$

$0.72 \mathrm{~m}$

$0.7 \mathrm{om}$

o.64m

o.6om

$0.57 \mathrm{~m}$

$0.56 \mathrm{~m}$

$0.51 \mathrm{~m}$

Source: From Manners-Bell, J. 2014. Global Logistics Strategies, London: Kogan Page.

and the industry is now the most consolidated section of shipping ${ }^{3}$. The world's largest players in 2012 are listed in table 13.

If we now turn to the reefer capacity of the container lines (see table 14), we see that Maersk is quite naturally the largest player. However, what is surprising is that Maersk has more than three times the container capacity, in terms of reefer containers, of the second largest container line MSC. If we consider the number of reefer plugs in the north-south trade, Maersk was the biggest player in 2016 with 103000 plugs, followed by Hamburg Süd with 87000 and Mediterranean Shipping Co. with $85000^{4}$.

As has been mentioned in the second chapter, the container lines overtook the specialized carriers in terms of reefer capacity in 1997. In 2013, as table 14 shows, the capacity of the container lines was $74 \%$ of the total global reefer capacity, and it is expected that in 2019 , the share will reach $83 \% 0^{5}$. The trend reflects the strategic intent of the container lines to grow their reefer business, due to the rates in the reefer business and that attracting reefer cargo addresses overcapacity. Furthermore, the growth is possible both because of growing

3 See for example Poulsen, R.T. 2007. Liner shipping and Technological Innovation: Ostasiat and the Container Revolution, 1963-75, Scandinavian Economic History Review, 55: 83-100.

4 "Reefer ships forecast to lose share to container vessels" Journal of Commerce 31 January 2016. $<$ http://www.joc.com/maritime-news/container-lines/reefer-ships-bucked-trend-2015-dy namar-reports_20160131.html>.

5 "A Perspective on Refrigerated Container Trade Growth". GeP Mind. <https://www.gep.com/ mind/blog/perspective-refrigerated-container-trade-growth>. 


\section{Container line}

Maersk Line

Mediterranean Shipping Company

CMA CGM

Hamburg Süd

APL

CSAV

Hapag-Lloyd

Evergreen

MOL

Hanjin

Other container lines

Specialized reefers
Reefer capacity market share

(available equipment)

a Drewry Reefer Shipping Market Review and Forecast, Annual Report, 2013/14, retrieved from Duggan, W.C. "Carrier perspective on Refrigerated Shipping", Maersk Line. <http://agtrans. org/wp-content/uploads/2014/07/william-dugan-2014.pdf>.

trade flows and because of the withdrawal of specialized reefer capacity. In 2016, container lines were positive about the prospects in the reefer trades. Nick Fafoutis, chief commercial officer at the French container lines CMA CGM, believes that container carriers will continue to capture market share at the expense of specialized carriers, but, he claims that "Adversaries can become complementary partners" suggesting that the increasing market demand in both emerging and developed economies is positive for both container lines and specialized carriers ${ }^{6}$. Not only do the container lines grow at the expense of specialized carriers. They also gradually move into produce that have traditionally been carried by specialized reefers, for example bananas. In 2015, the container lines carried $55 \%$ of the total volume of bananas compared with $44 \%$ in $2012^{7}$.

6 “Container lines' reefer investments reap new services". Journal of Commerce 9 July 2016. $<$ http://www.joc.com/international-logistics/cool-cargoes/reefer-investments-ongoing-con tainer-carriers_20160709.html>.

7 <https://theloadstar.co.uk/coolstar/container-lines-going-bananas-to-grab-a-bit-more-mar ket-share/ $>$. 
A full description of the container lines' strategies in the reefer trades is outside the scope of this book. However, we will briefly describe the history, focusing on the reefer business, of Maersk Line, which is not only the largest container line, but also the largest in terms of reefer plugs and reefer equipment.

Maersk is the largest player in the market for carrying refrigerated cargo ${ }^{8}$. Starting out as a steamship owner in the late 19th century, the family business grew to be one of the world leaders in containerized liner shipping. Maersk Line developed a line from the us East and West coast to Asia in the late 1920s, and during the 1950 and 1960 added ports in the North Atlantic, West Africa, the Middle East and Europe.

In the 1960s, similarly to other liner companies, Maersk had to decide how to face the growing challenge of containerization of cargo. When the containerization challenge appeared, Maersk had already taken a decision to move away from break-bulk and unitize cargo around the pallet. By the end of the 1960s many competitors, such as Sea-Land, APL, NYK and Mitsui had either containerized or were about to embark on containerization. In particular, Maersk watched the developments in the Far East Freight Conference (FEFC) with concern. Kawasaki Kisen Kaisha and Maersk had since the latter half of the 1960 s collaborated on a Europe-Asia service. In the FEFC, they saw how other competitors moved swiftly towards containerization, and in the winter of 1970, it was announced that from 1972, at least 27 container ships would be deployed in the Europe-Asia services. In response to this paradigm shift, the year after, in 1971, Maersk and Kawasaki Kisen ordered one container ship each. Eventually, due to 'circumstances', Kawasaki Kisen Kaisha cancelled the agreement with Maersk, but since Maersk was committed to the trade, they continued to serve the Europe-Asia service with seven conventional ships, and chartered out the cellular container ship that they had ordered. One of many reasons for the slow venturing into containerization was due to the still profitable conventional liner services, and the fact that the liner division was committed to and strongly believed in conventional vessels, albeit with container capacity on deck. When the new Maersk Container Line division was created, the upper management could not just transfer people from Maersk Line into

8 This part is based on Jephson and Morgen 2014 and Jensen, L. 2014. Culture shock in Maersk Line - From Entrepreneurs and Kings to Modern Efficiency, Copenhagen: Vespucci Maritime Publishing. 
the new organization - in fact, operating a container service is very different from operating conventional break-bulk and pallet services. After this slow start, the Panama Line was containerized resulting in an order of nine "A-class" container vessels that were delivered between 1975 and 1976 . This shows that many companies struggled to face the growing challenge from containerization. Also, the rigidities that exist in any organization when facing a paradigm shift are obvious. Maersk, however, successfully adapted to the trend of containerization, which has proved successful up to the present ${ }^{9}$.

When it comes to refrigerated cargo, Maersk did some early ventures into owning reefer vessels, such as the M.S. Francine, acquired in 1936 and chartered out to J. Lauritzen, and owning conventional break-bulk carriers with reefer capacity from the mid-1930s. The move into containerized reefer cargo came with the A-class ships delivered in 1975-1976. They were equipped for ten refrigerated containers, and it was forecasted that the plugs would be used about 20 per cent of the time ${ }^{10}$. The reason for the conservative prognosis was probably due to two reasons. First, most of the refrigerated cargo was moved in dedicated reefers, which had made a solid inroad into refrigerated liner traffic in the 1960s. Second, the average size of the reefer vessels grew, which absorbed most of the growth in the market for maritime refrigerated trades. However, reefers had a significant drawback - the market price of refrigerated cargo (for example, bananas) would drop when large quantities of cargo arrived at the same port, as the market would be temporarily flooded. The conventional reefers dominated the market however, but the refrigerated container traffic by liner companies were starting to carry frozen meat in the early 1970 s and also non-traditional commodities, such as photographic film and enzymes. The arrival of the Maersk Newton ships in the 1980s significantly increased refrigerated cargo capacity.

Although refrigerated containers were bought at a cost of 3.2-3.7 times the price of standard dry equipment, Maersk saw the logic of continuing to explore the reefer market. In an internal report at Maersk, produced in 1986, the investigative team described the potential for penetrating the reefer market as follows:

- This is a technically complicated operation calling for reliability, competence and flexibility in the carrier

- Overall cost comparisons between self-contained and port-hole reefers clearly indicate that up to 300 units per ship, self-contained units were more

$9 \quad$ Jephson and Morgen 2014, ch. 2-3.

10 Jephson and Morgen 2014, p. 96, 111. 
cost-effective and flexible in terms of temperature, commodity stowage, refrigerating techniques and terminal handling

- Containerised solutions can be offered at freight rates competitive with traditional reefer tramp vessels and still be an attractive business

In mid-1986, Maersk Line's reefer capacity amounted to 160 plug connections per ship (in 28 ships) or an estimated 5 percent of the world reefer capacity. High cube reefer containers ( $40 * 8 \% 9.5$ feet) were developed and 1300 such containers were in operation in the Maersk fleet. The margins for refrigerated cargo was at Maersk considered to be good, ranging from 3900 USD to 6000 USD per container in the major trades ${ }^{11}$. It is stated that the "reefer market shares in the main trades were doing well, despite rates being under pressure in several areas of the world"12.

Certainly, during the history of Maersk, the main strategic aim was not to develop refrigerated trades, but Maersk did pay attention to this growing segment. For example, in 1985, the Panama Line was divided into two lines, where the first line would call at Japanese ports directly when arriving from the Us. This allowed Maersk to penetrate the major reefer trade from the us West Coast to Japan ${ }^{13}$. Another report was presented in 1986 about the trade to Australia. Five years earlier a study had shown that the Australia service might be viable, but at that time, there was no spare capacity on the Maersk ships. The follow-up report showed that positive results could be generated for Maersk Line. It is argued that these ventures made the size of the reefer market from this area visible.

In early 1992, a proposal was put forward to buy 150040 -foot reefer containers to supplement the existing fleet, and the order was signed. During the same year, two Maersk representatives visited a number of South American countries to evaluate if there was a market for the company's operations. They visited ports and also received a positive response from potential customers:

We visited a major fruit exporter who in no uncertain terms invited Maersk Line to participate in their seasonal movements ... Past good experience with shipments to Japan had convinced shippers that the reefer container (porthole concept disliked), was here to stay and would eventually capture the market. The service was inaugurated in $1993^{14}$.

\footnotetext{
11 Jephson and Morgen 2014, p. 111-113.

12 Jephson and Morgen 2014, p. 142.

13 Jephson and Morgen 2014, p. 130-131.

14 Jephson and Morgen 2014, p. 229.
} 
In the mid-1990s, the upper management of Maersk, in a report, noted that the reefer container fleet was growing at roughly double the rate of growth of the general containerised trade. Also, Asian importers controlled 70-80 percent of reefer movements from the us and Europe and strengthened sales efforts were needed to ensure the protection of Maersk Line's position. Moreover, "additional services to New Zealand and South Africa were expected to help Maersk Line grow in the reefer segment". Yet another move in the reefer market in 1997 was the introduction of the 'super-reefers', reefer containers catering mainly to Japanese fish importers providing temperatures as low as -6o degrees Celsius, suitable for transport of sea urchins, swordfish, food cultures, and pharmaceuticals ${ }^{15}$. In 1999, some ships that were on order carried 2500-3000 TEU, with 700 reefer plugs ${ }^{16}$.

Apart from the ships, in 1996, a reefer container plant was built by Maersk Container Industries (MCI) in Tinglev, Denmark, followed by an acquisition of a Chinese factory in 1999. One year before the acquisition of the factory in Qingdao, MCI had launched the Star Cool project to develop a reefer machine that was both reliable and that had a low energy consumption. Star Cool was achieved in 2005, and in 2012, 100 ooo units had been sold.

As is well known, since the end of the 1980s Maersk had been on an acquisition trail, acquiring companies such as the Danish East Asiatic Company, Safmarine, and P\&O NedLloyd. After having merged in 1999 with Sealand, the pioneer in containerization, Maersk-Sealand as the company was called, had become the largest reefer operator. Maersk-Sealand expected a growth in the reefer segment of 5.8 percent per year, where the main growth was in the frozen goods segment. Jephson and Morgan identify that the main strengths of Maersk-Sealand were in the fish, meat and deciduous fruit markets. Maersk-Sealand used high-technology reefer equipment, such as controlled atmosphere, high humidity or super-reefers. However, Maersk-Sealand's participation in the largest conventional reefer trade, namely bananas, was just 1.8 percent ${ }^{17}$.

The 2007-2008 financial crisis had a significant impact on Maersk Line's business, and in 2011, Maersk Line CEO Soren Skou described the situation in Maersk Line as a need to "get back to black". Regarding the reefer operations, his remarks are interesting:

\footnotetext{
15 Jephson and Morgen 2014, p. 249-250.

16 Jephson and Morgen 2014, p. 252.

17 Jephson and Morgen 2014, p. 271.
} 


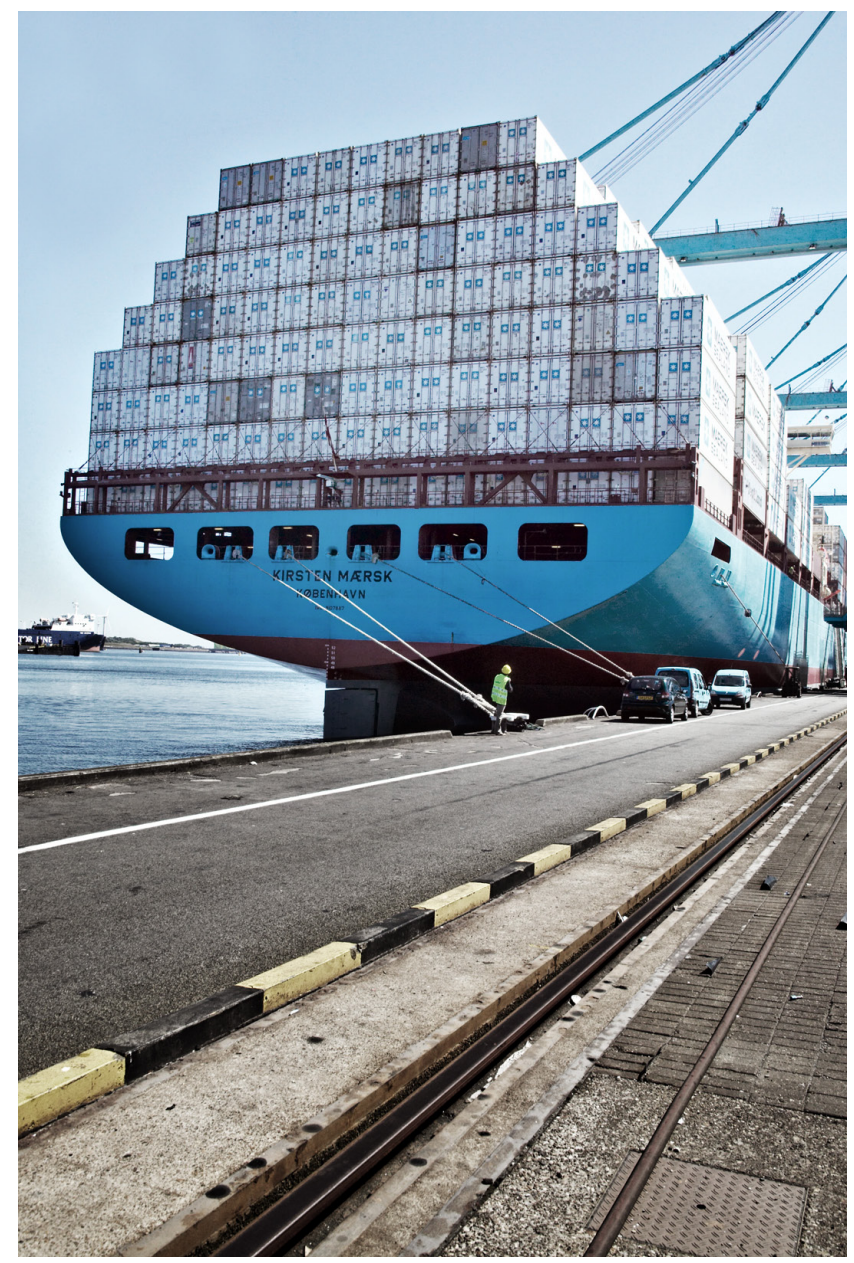

FIGURE 22

Modern container vessels have the ability to carry enormous quantities of reefer containers

PHOTO: MAERSK LINE

The reefer market is hugely important to us, and our mindset has been that every reefer is gold, that this is a great business. But when you look at the investment, where a reefer is four to five times the cost of a dry container, plus the plugs and power on the ships, and the fuel bill for running the reefers, then the return on the reefer business is disappointing and we have to get our returns up. I think that on the reefer side, we may have to invest a little bit of market share in getting prices up, not a lot, as there is not a huge amount of excess reefer capacity out there. We have a good chance of making that business attractive again. ${ }^{18}$ 
Jephson and Morgen state that Maersk had invested over 1.9 billion USD in a reefer fleet of 105 ooo FFE of reefers. Following up on Skou's analysis was a substantial price increase with effect from the first of January 2013 to bring reefer business Back to Black. In September 2012, Maersk announced a rate hike of 1500 USD per container ${ }^{19}$. A month later, the second largest reefer carrier, Mediterranean Shipping Company did the same ${ }^{20}$.

According to an interview with Shereen Zerkani, Global Head of Reefer Management of Maersk Line, in 2015, the low oil price has resulted in a comeback for some older, specialized reefers. However, she still believes that the future trend is toward containerization. Although at present the specialized reefers can thrive in the market, in the future their impact will be reduced.

In the past 10-12 years there's been a clear development toward containerization, as the bigger and more traditional container ships have taken over a big portion of reefer transports from the specialized reefer fleet. This development will continue ${ }^{21}$.

\section{Summary}

The independent reefer operators have always been developing alongside the liner companies. In this part we have discussed how the liner companies saw increased competition from the new, wild reefer operators, that could offer more direct lines with specialized vessels. This competition became increasingly difficult since the liner companies were forced to adapt to the trend of containerization in the 1960s and 1970s. At that time, the infrastructure, both container equipment and land-based facilities was not fully developed for the refrigerated trades. Slowly, the container lines started to take reefer cargo from the independent operators, from meat and fish to more sensitive cargo like fruit. The container lines, particularly Maersk, has seen the reefer cargo not only as the fastest growing segment but also as a suitable back-haul cargo. The market decline for the independent reefer operators since the mid-199os can therefore to a great extent be attributable to the come-back of liner companies.

\footnotetext{
19 Carriers put money on hybrid ship designs, Shanghai Shipping Exchange, 19 November 2012, <http://en.sse.net.cn/info/detailen.jsp?id=310233>.

20 "MSC applies 1500 dollar reefer rate hike globally Jan. 1". American Shipper 24 October 2012. <http://www.americanshipper.com/main/news/msc-applies-1500-reefer-rate-hikeglobally-jan-1-51647.aspx?taxonomy=Industries\#hide $>$.

21

"Maersk Line invests big-time in its reefer fleet". Shippingwatch 28 January 2016. <http:// shippingwatch.com/carriers/Container/article8393934.ece>.
} 
In an attempt to reposition themselves in the face of the comeback of the liner companies the operators started to position themselves as operating conventional reefers as opposed to containers, something that we will come back to in the chapters 12 and 13 . 